\title{
Coupling of thraustochytrids and POM, and of bacterio- and phytoplankton in a semi-enclosed coastal area: implication for different substrate preference by the planktonic decomposers
}

\author{
Hiroyuki Kimura, Makoto Sato, Chino Sugiyama, Takeshi Naganuma*
}

School of Biosphere Sciences, Hiroshima University, 1-4-4 Kagamiyama, Higashi-Hiroshima 739-8528, Japan

\begin{abstract}
Abundances of planktonic thraustochytrids and bacterioplankton were investigated in the Seto Inland Sea, Japan, with reference to concentrations of potential growth substrates such as dissolved organic carbon (DOC) and particulate organic carbon (POC) concentration and of phytoplankton (chlorophyll a concentration). Thraustochytrid and bacterioplankton cells were stained with acriflavine and acridine orange, respectively, and directly counted by epifluorescence microscopy. Thraustochytrids occurred in the water column at a density of $0.9 \times 10^{2}$ to $2.1 \times 10^{4}$ cells l$^{-1}$, with an overall average $( \pm \mathrm{SD})$ of $3.1 \pm 4.0 \times 10^{3} \mathrm{cells}^{-1}$. Bacterioplankton were found in the water column at a density of $1.1 \times 10^{9}$ to $6.6 \times 10^{10}$ cells $\mathrm{l}^{-1}$, with an overall average of $4.8 \pm 7.0 \times 10^{9}$ cell $^{-1}$. Thraustochytrid abundance was significantly correlated primarily to POC concentration $(r=0.547, \mathrm{p}<0.001)$ and secondarily to chlorophyll a concentration $(\mathrm{r}=0.318, \mathrm{p}<0.001)$. By contrast, bacterioplankton concentration was significantly correlated primarily to chlorophyll a concentration $(r=0.498, p<$ $0.001)$ and secondarily to DOC concentration $(r=0.236, p=0.002)$ but negatively to POC concentration $(\mathrm{r}=0.143, \mathrm{p}=0.068)$. Phytoplankton-derived POC accounted for a certain fraction (only ambiguously estimated at 20 to $60 \%$ ) of total POC, and about $20 \%$ of POC was ascribable to bacterioplankton biomass. The remaining POC was assumed to be non-phytoplanktonic, non-bacterioplanktonic sources such as phytodetritus and terrigenous matter. Therefore, it is suggested that bacterioplankton abundance may depend primarily on phytoplankton-derived DOC whereas thraustochytrid abundance is more influenced by non-phytoplankton, non-bacterioplankton POC. That is, planktonic degraders, thraustochytrids and bacterioplankton, decompose substrates of different origins and sizes. The potential ecological importance of the thaustochytrids as active degraders of POC and as an alternative food source is discussed.
\end{abstract}

KEY WORDS: Thraustochytrid · Fungoid protist $\cdot$ Bacterioplankton $\cdot$ Abundance $\cdot$ Particulate organic carbon · Dissolved organic carbon · Chlorophyll a

\section{INTRODUCTION}

Thraustochytrids are obligately marine- and estuarine-dwelling protists (Moss 1986), and were formerly classified as the lower fungi, heterotrophic eukaryotic microorganisms. This group is characterized by the presence of an ectoplasmic net and a cell wall composed of non-cellulosic, sulfurylated scales (Darley et

*Corresponding author. E-mail: takn@hiroshima-u.ac.jp al. 1973). Thraustochytrids are now classified in the phylum Heterokonta within the kingdom Stramenopila (Patterson 1999). The phylum Heterokonta also includes the species of diatoms and brown algae as well as the oomycetes (Cavalier-Smith et al. 1994).

Previous studies have determined the abundance of thraustochytrids over a wide range of habitats, including the water column, algae, particulate detritus and invertebrates (Raghukumar et al. 1990, Riemann \& Schaumann 1993, Frank et al. 1994, Naganuma et al. 1998, Kimura et al. 1999). A rapid direct detection tech- 
nique using the fluorogenic dye acriflavine was developed and used for the enumeration of thraustochytrids (Raghukumar \& Schaumann 1993). The acriflavine fluorescence technique relies on the fact that the wall and nucleus of thraustochytrid cell fluoresce differently in red and blue-green, respectively, under blue-light excitation. This dual fluorescence distinguishes thraustochytrids from other protists and detritus. In recent studies, 18S rDNA analysis identified thraustochytrids in the pico- and nanoplanktonic assemblages from the equatorial Pacific Ocean and the Antarctic polar front (López-García et al. 2001, Moon-van der Staay et al. 2001). Note that the enumeration based on acriflavinstaining may include protozoan cysts (leading to overestimation) and exclude thraustochytrid zoospores (leading to underestimation). Contribution of this overand underestimation should be evaluated in future studies by using a more specific technique such as immunofluorescence microscopy.

The fungoid protists, thraustochytrids, are sized largely between 3.5 and $20 \mu \mathrm{m}$ in diameter (Raghukumar \& Schaumann 1993, Naganuma et al. 1998), and are larger than bacterioplankton $(<1 \mu \mathrm{m}$, Naganuma \& Miura 1997). Thus, thraustochytrids are thought to serve as important food sources for picoplankton feeders and contribute to the increase in the efficiency of pelagic secondary production (Naganuma et al. 1998, Kimura et al. 1999). Thaustochytrids uniquely produce polyunsaturated fatty acids such as docosapentaenoic acid and docosahexaenoic acid (Nakahara et al. 1996), which may be important nutritionally for the growth of fish larvae (Raghukumar 1986, Raghukumar \& Balasubramian 1991).

Another ecological role of thraustochytrids is decomposition of refractory organic substrates in marine ecosystems (Perkins 1973). Thraustochytrids have been reported to occur in association with decaying fecal pellets of zooplankton such as salps (Raghu-

Table 1. Sites and months of sample collection, corresponding area names, and range of surface water temperature observed during each cruise (July and September 2000). -: samples were not collected + +: samples were collected

\begin{tabular}{|c|c|c|c|c|}
\hline Site no. & Area name & & $\begin{array}{l}2000 \\
-29.0^{\circ} \mathrm{C}\end{array}$ & $\begin{array}{c}\text { Sep } 2000 \\
23.1-27.6^{\circ} \mathrm{C}\end{array}$ \\
\hline 1 to 3 & Hyuga Nada & Kuroshio-affected $^{\mathrm{a}}$ & - & + \\
\hline 4 & Bungo Channel & Outer Seto Inland Sea & - & + \\
\hline 5 to 14 & Iyo Nada & Seto Inland Sea & + & + \\
\hline 15 to 17 & Hiroshima Bay & Seto Inland Sea & + & + \\
\hline 18 to 22 & Hiuchi Nada & Seto Inland Sea & + & - \\
\hline 23 & Bisan Seto & Seto Inland Sea & + & - \\
\hline 24 to 29 & Harima Nada & Seto Inland Sea & + & - \\
\hline 30 to 37 & Osaka Bay & Seto Inland Sea & + & - \\
\hline 38 to 42 & Kii Channel & Seto Inland Sea & + & - \\
\hline
\end{tabular}

kumar \& Raghukumar 1999) and plant material such as algal tissue (Miller \& Jones 1983, Sathe-Pathak et al. 1993, Sharma et al. 1994), cellulosic material (Fell \& Master 1973, Findlay et al. 1986) and mangrove leaf (Ulken 1984, Raghukumar 1988, Raghukumar et al. 1994, Bremer 1995). These observations suggest that thraustochytrids may play a definite role in the dynamics of particulate organic matter (POM) in the marine ecosystem. On the other hand, it is known that dissolved organic matter (DOM), such as exudate DOM from phytoplankton (Larsson \& Hagström 1979) and terrigenous DOM in river water (Zweifel et al. 1995, Kuparinen et al. 1996, Rolff \& Elmgren 2000), is used as a growth substrate for bacterioplankton (Zweifel et al. 1993, Moran \& Hodson 1994, Hullar et al. 1996). However, no work has been published on the correlation between the abundances of planktonic thraustochytrids and bacterioplankton and the concentrations of dissolved organic carbon (DOC), particulate organic carbon (POC) and chlorophyll a (chl a).

We report the distribution of planktonic thraustochytrids and bacterioplankton abundances in the Seto Inland Sea and their correlation with DOC, POC and chl a concentrations.

\section{MATERIALS AND METHODS}

Sample collection and site description. In total, 165 water samples were collected for determining the abundances of thraustochytrids and bacterioplankton and the concentrations of DOC, POC and chl a. Samples were collected with Van Dorn samplers from 42 sites at 3 depths $(1,5$ and $15 \mathrm{~m})$ during cruises by RV 'Toyoshio-maru' in July and September 2000. The samples were collected in the Seto Inland Sea and the Hyuga Nada area, Japan (Table 1, Fig. 1). The Van Dorn samplers were pre-washed and pre-rinsed with distilled water, and re-washed with seawater of the same site and depth immediately before sample collection.

Vertical profiles of water temperature, salinity and dissolved oxygen were monitored at each sampling site with a Sea Bird conductivity, temperature, depth profiler (CTD). Water temperature ranged from $15.1^{\circ} \mathrm{C}$ (Site $6,15 \mathrm{~m}$ depth) to $29.0^{\circ} \mathrm{C}$ (Site 20, $1 \mathrm{~m}$ depth) in July, and from $23.1^{\circ} \mathrm{C}$ (Site 11, $15 \mathrm{~m}$ depth) to $27.6^{\circ} \mathrm{C}$ (Site 1, $1 \mathrm{~m}$ depth) in September. Salinity ranged from $27.2 \mathrm{psu}$ (Site 34, $1 \mathrm{~m}$ depth) to 33.9 psu (Site 33, $15 \mathrm{~m}$ depth) in July, and from 30.7 psu (Site 17, $1 \mathrm{~m}$ 
Fig. 1. Site locations of sample collection in and near the Seto Inland Sea, Japan

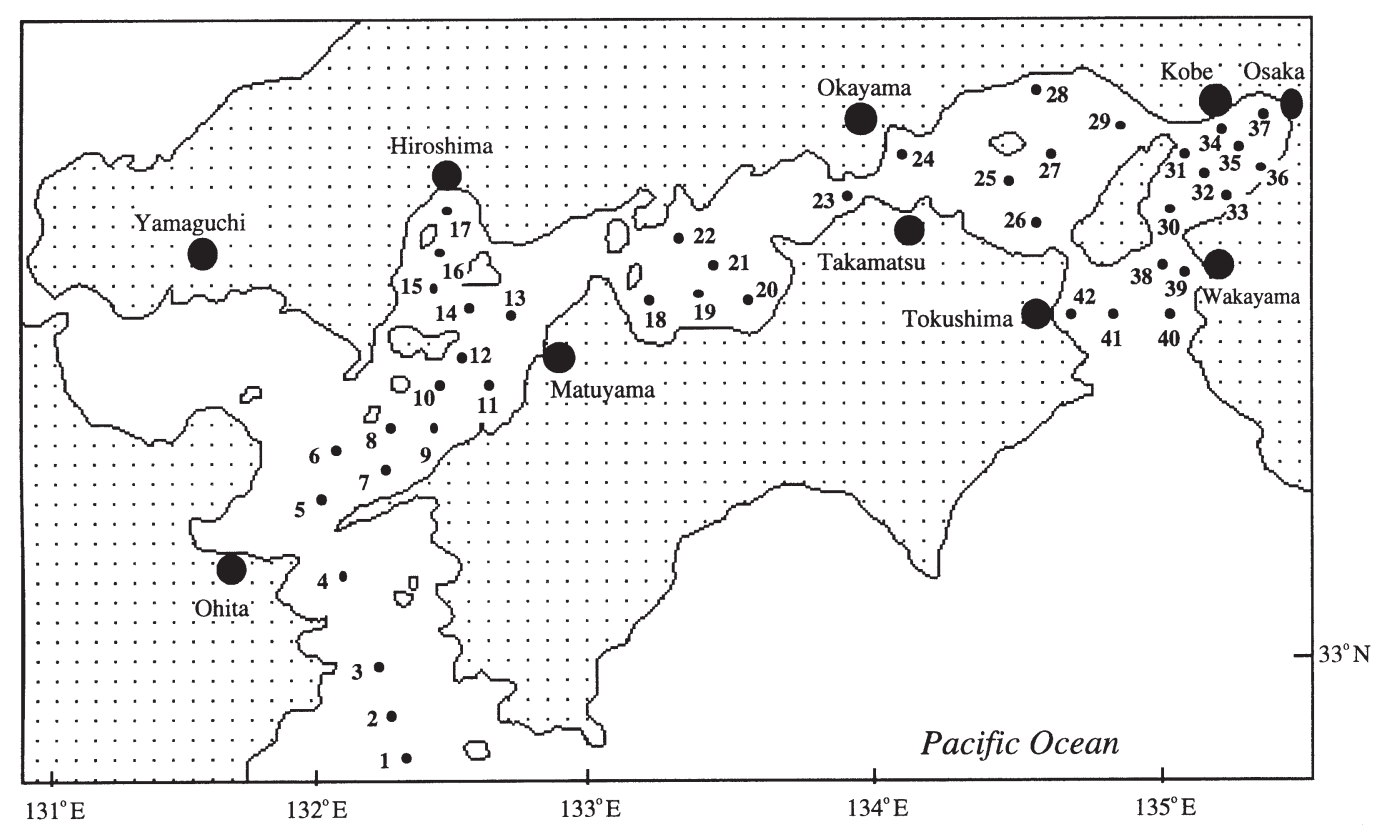

The limitation of the current staining technique is that zoospores of most thraustochytrid species lack cell walls (Moss 1986). Also, very small cells $(<5 \mu \mathrm{m})$ were not easily distinguishable because the cell wall-associated red fluorescence was weaker than the nucleusassociated green fluorescence. Thus, very small cells were not counted, and the counts reported in this study probably are underestimations.

Determination of DOC, POC and chl a concentrations. Immediately after sampling, $200 \mathrm{ml}$ of water samples was filtered through pre-combusted glass fiber filters $\left(450^{\circ} \mathrm{C}, 3 \mathrm{~h} ; 25 \mathrm{~mm}\right.$, Whatman $\left.\mathrm{GF} / \mathrm{F}\right)$, and both filtrate and filters were kept frozen at $-20^{\circ} \mathrm{C}$ until determination. DOC concentration in each filtrate was measured with a total organic carbon analyzer (Shimadzu Co. Ltd, Kyoto, Japan). POC on each filter was measured with a CHN analyzer (Model MT-5, Yanaco CO. Ltd, Kyoto, Japan). Chl a concentration was calculated from the fluorescence intensity, whose vertical profile was monitored at each sampling site with a Sea Bird CTD. The fluorescence intensity was calibrated with known amounts of chl a (Sigma) dissolved in dimethyl formamide at $-20^{\circ} \mathrm{C}$ (Parsons et al. 1984).

\section{RESULTS AND DISCUSSION}

\section{DOC, POC and chl a concentrations}

General distributions of DOC, POC and chl a concentrations were as follows: DOC concentration varied from 0.3 (Site $4,5 \mathrm{~m}$ depth, September) to $4.3 \mathrm{mg} \mathrm{l}^{-1}$ (Site 9, $1 \mathrm{~m}$ depth, September). POC concentration green and red, respectively. 
ranged from 0.11 (Site 2, $5 \mathrm{~m}$ depth, September) to $3.3 \mathrm{mg} \mathrm{l}^{-1}$ (Site 17, $15 \mathrm{~m}$ depth, July). Calculated chl a concentration was within the range of 0.172 (Site 1, $5 \mathrm{~m}$ depth, September) to $30.0 \mu \mathrm{g}^{-1}$ (Site 34, $1 \mathrm{~m}$ depth, July).

\section{Abundance of planktonic thraustochytrids and bacterioplankton}

The abundance of planktonic thraustochytrids in the Seto Inland Sea (Table 2) varied from $0.86 \times 10^{2}$ (Site 7, Iyo Nada, $1 \mathrm{~m}$ depth in September) to $2.14 \times$ $10^{4}$ cells $\mathrm{l}^{-1}$ (Site 17, Hiroshima Bay, $1 \mathrm{~m}$ depth in July), with an overall average $( \pm \mathrm{SD})$ of $3.11 \pm 4.00 \times$ $10^{3}$ cells $\mathrm{l}^{-1}(\mathrm{n}=165)$. The population density of bacterioplankton varied within a relatively narrow range from $1.10 \times 10^{9}$ (Site 3, Hyuga Nada, $1 \mathrm{~m}$ depth in September) to $6.56 \times 10^{10}$ cells $1^{-1}$ (Site 33, Osaka Bay, $1 \mathrm{~m}$ depth in July), with an overall average of $4.79 \pm$ $7.02 \times 10^{9}$ cells $\mathrm{l}^{-1}(\mathrm{n}=165)$. Previous studies reported an average thraustochytrid abundance of $10^{3}$ to
$10^{4}$ cells $\mathrm{l}^{-1}$ (Naganuma et al. 1998, Kimura et al. 1999) and an average bacterioplankton abundance of

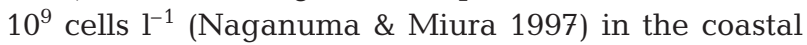
Seto Inland Sea and adjacent open waters. The abundance determined in this study was in good agreement with the previous reports. The depth-to-depth variation in the abundances of thraustochytrids and bacterioplankton is shown in Table 3. Abundances of thraustochytrids and bacterioplankton were generally high in the top $1 \mathrm{~m}$ of water and decreased with depth. However, the overall correlation $(n=55)$ of abundance and depth was not significant for thraustochytrids $(\mathrm{r}=0.107, \mathrm{p}=0.170)$ and bacterioplankton ( $\mathrm{r}=0.125, \mathrm{p}=0.109$ ).

The highest abundance of thraustochytrids, both site-/depth-specific and site-/depth-averaged, was found in Hiroshima Bay (Sites 15 to 17), where all the determined parameters were above the averages (Table 2). The highest POC concentration was also seen in Hiroshima Bay, and this coincidence suggested that thraustochytrid abundance and POC concentration are connected.

Table 2. Area-/depth-averaged abundances of thraustochytrids (Thra) and bacterioplankton (Bact), and concentrations of dissolved organic carbon (DOC), particulate organic carbon (POC) and chlorophyll a (Chl a) in the Seto Inland Sea, Japan

\begin{tabular}{|c|c|c|c|c|c|c|}
\hline Site & Sea area name & 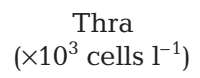 & $\begin{array}{c}\text { Bact } \\
\left(\times 10^{9} \text { cells l }^{-1}\right)\end{array}$ & $\begin{array}{c}\text { DOC } \\
\left(\mathrm{mg} \mathrm{l}^{-1}\right)\end{array}$ & $\begin{array}{c}\text { POC } \\
\left(\mathrm{mg} \mathrm{l}^{-1}\right)\end{array}$ & $\begin{array}{c}\text { Chl a } \\
\left(\mu \mathrm{g} \mathrm{l}^{-1}\right)\end{array}$ \\
\hline \multicolumn{7}{|l|}{ July } \\
\hline 5 to 14 & Iyo Nada & $4.46 \pm 4.51$ & $2.47 \pm 0.42$ & $2.13 \pm 0.29$ & $1.11 \pm 0.38$ & $2.00 \pm 1.26$ \\
\hline 15 to 17 & Hiroshima Bay & $8.62 \pm 7.93$ & $6.41 \pm 1.15$ & $2.30 \pm 0.43$ & $1.96 \pm 1.02$ & $7.03 \pm 6.20$ \\
\hline 18 to 22 & Hiuchi Nada & $1.64 \pm 2.11$ & $3.12 \pm 1.04$ & $1.43 \pm 0.57$ & $0.88 \pm 0.13$ & $1.44 \pm 1.22$ \\
\hline 23 & Bisan Seto & $1.87 \pm 0.81$ & $3.39 \pm 0.29$ & $1.52 \pm 0.49$ & $1.41 \pm 0.51$ & $4.21 \pm 0.14$ \\
\hline 24 to 29 & Harima Nada & $3.68 \pm 3.64$ & $3.70 \pm 0.39$ & $2.64 \pm 0.34$ & $0.78 \pm 0.54$ & $4.11 \pm 2.12$ \\
\hline 30 to 37 & Osaka Bay & $4.00 \pm 4.50$ & $15.7 \pm 13.8$ & $2.23 \pm 0.39$ & $0.71 \pm 0.48$ & $7.81 \pm 7.68$ \\
\hline 38 to 42 & Kii Channel & $4.14 \pm 2.43$ & $4.16 \pm 1.66$ & $2.39 \pm 0.27$ & $0.52 \pm 0.10$ & $4.04 \pm 2.15$ \\
\hline 5 to 42 & Average & $4.09 \pm 4.44$ & $5.88 \pm 8.14$ & $2.11 \pm 0.48$ & $0.94 \pm 0.59$ & $4.21 \pm 4.72$ \\
\hline \multicolumn{7}{|c|}{ September } \\
\hline 1 to 3 & Hyuga Nada & $1.43 \pm 1.21$ & $1.34 \pm 0.14$ & $1.60 \pm 0.69$ & $0.13 \pm 0.02$ & $0.28 \pm 0.08$ \\
\hline 4 & Bungo Channel & $1.16 \pm 0.12$ & $1.87 \pm 0.04$ & $1.09 \pm 0.76$ & $0.21 \pm 0.01$ & $2.90 \pm 0.53$ \\
\hline 5 to 14 & Iyo Nada & $0.48 \pm 0.27$ & $1.91 \pm 0.47$ & $1.69 \pm 0.59$ & $0.27 \pm 0.08$ & $4.92 \pm 2.21$ \\
\hline 15 to 17 & Hiroshima Bay & $1.83 \pm 1.33$ & $5.19 \pm 3.11$ & $2.05 \pm 0.61$ & $0.46 \pm 0.15$ & $7.16 \pm 4.29$ \\
\hline 1 to 17 & Average & $0.93 \pm 0.93$ & $2.38 \pm 1.86$ & $1.70 \pm 0.64$ & $0.27 \pm 0.13$ & $4.38 \pm 3.24$ \\
\hline 1 to 42 & Total Average & $3.11 \pm 4.00$ & $4.79 \pm 7.02$ & $1.99 \pm 0.56$ & $0.73 \pm 0.58$ & $4.26 \pm 4.31$ \\
\hline
\end{tabular}

Table 3. Average abundance of thraustochytrids (Thra) and bacterioplankton (Bact), phytoplankton (Chl a), and eutrophical parameters: dissolved organic carbon (DOC), particulate organic carbon (POC) concentration and salinity (S)

\begin{tabular}{|c|c|c|c|c|c|c|}
\hline & $\begin{array}{c}\text { Thra } \\
\left(\times 10^{3} \text { cells } 1^{-1}\right)\end{array}$ & $\begin{array}{c}\text { Bact } \\
\left(\times 10^{9} \text { cells l}^{-1}\right)\end{array}$ & $\begin{array}{c}\text { Chl } a \\
\left(\mu \mathrm{g} \mathrm{chl} a l^{-1}\right)\end{array}$ & $\begin{array}{c}\text { DOC } \\
\left(\mathrm{mg} \mathrm{l}^{-1}\right)\end{array}$ & $\begin{array}{c}\text { POC } \\
\left(\mathrm{mg} \mathrm{l}^{-1}\right)\end{array}$ & $\begin{array}{c}\mathrm{S} \\
(\mathrm{psu})\end{array}$ \\
\hline Overall $(\mathrm{n}=165)$ & $3.11 \pm 4.00$ & $4.79 \pm 7.00$ & $4.26 \pm 4.31$ & $1.99 \pm 0.56$ & $0.73 \pm 0.58$ & $32.76 \pm 0.88$ \\
\hline $1 \mathrm{~m}(\mathrm{n}=55)$ & $3.75 \pm 4.50$ & $5.94 \pm 9.85$ & $4.44 \pm 4.91$ & $2.13 \pm 0.63$ & $0.87 \pm 0.69$ & $32.57 \pm 1.19$ \\
\hline $5 \mathrm{~m}(\mathrm{n}=55)$ & $3.00 \pm 4.08$ & $4.71 \pm 6.08$ & $4.64 \pm 5.22$ & $1.92 \pm 0.58$ & $0.66 \pm 0.43$ & $32.75 \pm 0.80$ \\
\hline $15 \mathrm{~m}(\mathrm{n}=55)$ & $2.61 \pm 3.32$ & $3.71 \pm 3.51$ & $3.70 \pm 2.15$ & $1.91 \pm 0.45$ & $0.67 \pm 0.58$ & $32.96 \pm 1.19$ \\
\hline
\end{tabular}



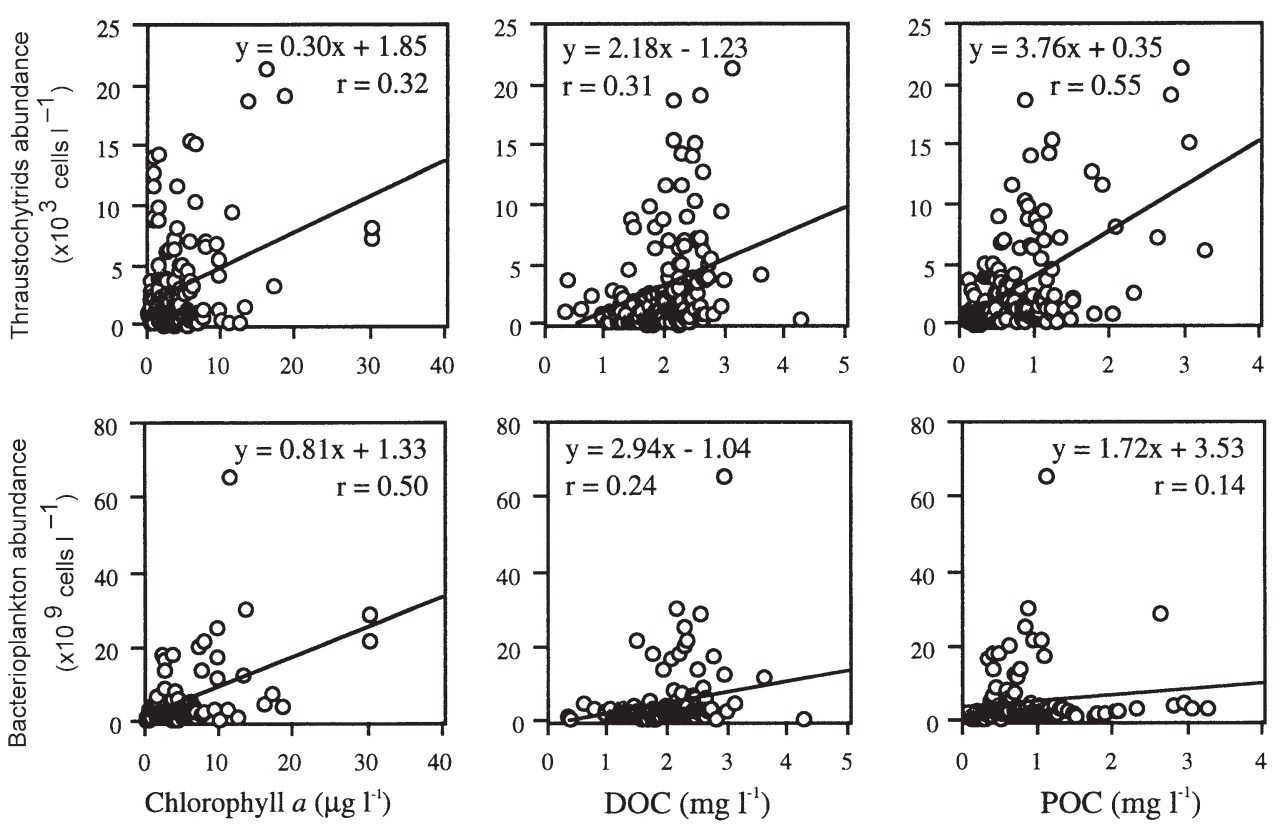

Fig. 2. Correlation between the decomposers (abundances of thraustochytrids and bacterioplankton) and environmental parameters of phytoplankton (chlorophyll $a_{l} \mu \mathrm{g} \mathrm{l}^{-1}$ ), dissolved organic carbon (DOC, $\mathrm{mg} \mathrm{C}^{-1}$ ) and particulate organic carbon (POC, mg $\mathrm{C}^{-1}$ ) concentrations. $\mathrm{n}=165$

In contrast, the highest bacterioplankton abundance, both site-/depth-specific and site-/depth-averaged, was found in Osaka Bay (Sites 30 to 37). The highest chl a concentration was also observed there, and thus a connection between bacterioplankton abundance and chl a concentration is implied in Osaka Bay.

Both Hiroshima Bay and Osaka Bay are highly eutrophic areas of the Seto Inland Sea (Okaichi \& Yanagi 1997). However, these bays are contrasted in the postulation that Hiroshima Bay has a close thraustochytrid-POC connection whereas Osaka Bay is rather dominated by a bacterioplankton-chl a connection. This postulation suggests that different ecological processes occur in these similarly eutrophic bays. lated to that of bacterioplankton and phytoplankton (chl a concentration) and to DOC and POC concentrations by linear regression $(y=a x+b)$. In particular, thraustochytrid abundance was most significantly correlated to POC concentration $(\mathrm{r}=0.547)$. The contribution of thraustochytrid-C to POC was calculated to be $0.076 \pm 0.079 \%$ of POC, based on $1.65 \times 10^{-4} \mu \mathrm{g} \mathrm{C}$ cell ${ }^{-1}$ (Kimura et al. 1999). Therefore, the involvement of thraustochytrid-C in POC is negligible. In a previous study (Raghukumar et al. 1990), thraustochytrid abundance and POC concentration were not significantly correlated in the pelagic Arabian Sea water. The study area, Seto Inland Sea, receives a river discharge of, for example, $62 \mathrm{~km}^{3} \mathrm{yr}^{-1}$ in 1985 (Yanagi 1996). This accounts for $7.6 \%$ of the volume of Seto Inland Sea $\left(816 \mathrm{~km}^{3}\right)$, and the residence time of river water was

\section{Correlation between decomposer abundances and environmental parameters}

The measured parameters thraustochytrid abundance $\left(\times 10^{3}\right.$ cells $\left.\mathrm{l}^{-1}\right)$, bacterioplankton abundance $\left(\times 10^{9}\right.$ cells $\left.\mathrm{l}^{-1}\right)$, chl a concentration $\left(\mu g \mathrm{l}^{-1}\right)$, DOC concentration (mg $\mathrm{C} \mathrm{l}^{-1}$ ) and POC concentration (mg C $\mathrm{l}^{-1}$ ) were correlated (Fig. 2). The correlation coefficients are shown in Table 4.

The abundance of planktonic thraustochytrids was positively corre-
Table 4. Correlation coefficients among thraustochytrids (Thra), bacterioplankton (Bact), phytoplankton ( $\mathrm{Chl} \mathrm{a),} \mathrm{dissolved} \mathrm{organic} \mathrm{carbon} \mathrm{(DOC),} \mathrm{particulate}$ organic carbon (POC) and salinity (S) by linear regression equations ( $\mathrm{n}=165$ ). ${ }^{*} \mathrm{p}<0.05 ;{ }^{* *} \mathrm{p}<0.01 ;{ }^{* * *} \mathrm{p}<0.001$

\begin{tabular}{|lcccccc|}
\hline & Thra & Bact & Chl $a$ & DOC & POC & S \\
\hline Thra & 1 & & & & & \\
Bact & $0.250^{* *}$ & 1 & & & & \\
Chl $a$ & $0.318^{* * *}$ & $0.498^{* * *}$ & 1 & & & \\
DOC & $0.307^{* * *}$ & $0.236^{* *}$ & $0.210^{* *}$ & 1 & 1 & \\
POC & $0.547^{* * *}$ & 0.143 & $0.277^{* * *}$ & $0.291^{* * *}$ & 1 \\
S & $-0.261^{* * *}$ & $-0.544^{* * *}$ & $-0.709^{* * *}$ & $-0.330^{* * *}$ & $-0.345^{* * *}$ & 1 \\
\hline
\end{tabular}


estimated to be 1.2 yr (Okaichi \& Yanagi 1997). The riverine influence with the input of terrigenous organic matter may favor the habitation of thraustochytrids. Although the riverine influence is rather small and locally limited compared with other major estuaries receiving greater river discharges (e.g., Biggs \& Howell 1984), the high abundance of thraustochytrids was connected to river discharge (Naganuma et al. 1998, Kimura \& Naganuma 2001). In this study, the correlation of thraustochytrid abundance with salinity was significant but correlation with POC, DOC and chl a concentrations was more significant (Tables 4 \& 5).

It is thus suggested that microbial processes such as secondary production and degradation may be influenced by riverine input of terrigenous DOC and POC. An average of $40 \%$ of POC in this area is estimated to be from phytoplankton and bacterioplankton biomass (discussed below), and a certain fraction of the remaining $60 \%$ would be of terrestrial origin. Terrigenous organic matter often contains refractory substrates such as cellulosic and phenolic compounds (Ittekkot 1988). Thraustochytrids can degrade these refractory substrates (Heald \& Odum 1970). Therefore, it might be hypothesized that the abundance of planktonic thraustochytrids is influenced by riverine input of terrigenous POC. This hypothesis is yet to be tested; however, circumstantial but supportive evidence has been reported (Kimura \& Naganuma 2001).

On the other hand, bacterioplankton abundance was most significantly correlated to chl a concentration ( $\mathrm{r}=$ $0.498)$ and secondarily to DOC $(r=0.236)$ concentration, as shown by the simple linear regression equation (Fig. 2), as previously shown in the Seto Inland Sea (Naganuma \& Miura 1997). The correlation between bacterio- and phytoplankton is well known for a wide variety of waters over large temporal and spatial scales (e.g., Fuhrman et al. 1980, Bird \& Kalff 1984, Cole et al. 1988, Cho \& Azam 1990, Bird \& Karl 1999). The bacterio- and phytoplankton coupling is viewed as bacterial dependence on the exudate DOC from phytoplankton (e.g. Cole et al. 1982, Chrost \& Faust 1983).

The abundances of planktonic thraustochytrids

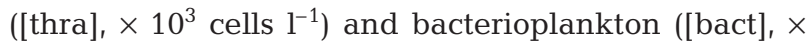

Table 5. Standard partial regression coefficients, or beta weight (b), for the multiple regression between the planktonic decomposers (thraustochytrids [thra] or bacterioplankton [bact]) and the environmental parameters [chl a], [DOC],

[POC] and [S] $(\mathrm{n}=165) .{ }^{*} \mathrm{p}<0.05 ;{ }^{* *} \mathrm{p}<0.01{ }^{*}{ }^{* * *} \mathrm{p}<0.001$

\begin{tabular}{|lllll|}
\hline & {$[\mathrm{chl} a]$} & {$[\mathrm{DOC}]$} & {$[\mathrm{POC}]$} & {$[\mathrm{S}]$} \\
\hline [thra $]$ & $0.245^{* *}$ & $0.160^{*}$ & $0.478^{* * *}$ & 0.131 \\
{$[$ bact $]$} & $0.235^{*}$ & 0.085 & -0.077 & $-0.376^{* * *}$ \\
\hline
\end{tabular}

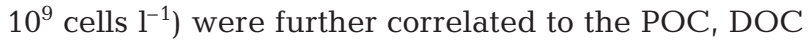
and chl a concentrations and salinity ([S], psu) by the multiple regression analysis as follows:

$$
\begin{array}{rlr}
{[\text { thra }]} & =3.287[\mathrm{POC}]+1.138[\mathrm{DOC}]+0.227[\mathrm{chl} \mathrm{a}] \\
& +0.595[\mathrm{~S}]-22.024 \quad(\mathrm{r}=0.596, \mathrm{n}=165) \\
& & \\
{[\text { bact }]} & =0.381[\mathrm{chl} \mathrm{a}]+1.059[\mathrm{DOC}]-0.930[\mathrm{POC}] \\
& -2.994[\mathrm{~S}]+99.846 \quad(\mathrm{r}=0.517, \mathrm{n}=165)
\end{array}
$$

Previous studies reported that the fungoid protists, thraustochytrids, are among the major marine decomposers of: plant-derived, often refractory, organic matter in riverine input (Bremer 1995, Bremer \& Talbot 1995, Valiela 1995); mangrove leaf litter (Ulken 1984, Raghukumar 1988, Raghukumar et al. 1994, Bremer 1995); phaneroganic material (Fell \& Master 1973, Findlay et al. 1986); brown algal tissue (Miller \& Jones 1983, Sathe-Pathak et al. 1993, Sharma et al. 1994); and fecal pellets of tunicate salp (Raghukumar \& Raghukumar 1999). It is presumed that relatively large-sized (3.5 to $20 \mu \mathrm{m})$ thraustochytrids degrade and utilize relatively large organic materials (micrometer-sized POM).

\section{Estimation of POC composition: implication of different preferences for decomposing substrates}

A certain fraction of POC is composed of phytoplankton biomass that is represented by chl a concentration. The ratio of phytoplankton- $\mathrm{C}$ to chl a concentation is generally regarded as 30 to $90 \mathrm{~g} \mathrm{C}$ per $\mathrm{g}$ [chl a] (Banse 1977). The ratio is calculated as the slope of the linear regression of [POC]-[chl a] correlation. The slope obtained in this study was 37.4 (Fig. 3), which is regarded as the minimum model $(y=a x+b)$. The $y$ intercept $\left(0.57 \mathrm{mg} \mathrm{C} \mathrm{l}^{-1}\right), 78.1 \%$ of total POC, is

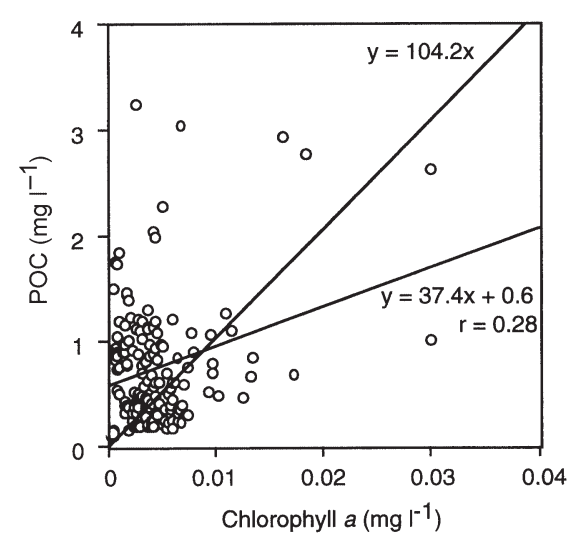

Fig. 3. Correlation between phytoplankton (chlorophyll $a_{1}$ $\mathrm{mg} \mathrm{l}^{-1}$ ) and particulate organic carbon (POC, mg $\mathrm{C}^{-1}$ ) concentrations. $\mathrm{n}=165$ 
regarded as non-phytoplanktonic POC by this model. On the other hand, forcing the $y$-intercept to zero (i.e., assuming that all POC is phytoplanktonic), the slope would be 104.2 (Fig. 3). This is regarded as the maximum model $\left(y=a^{\prime} x\right)$. Then the overall average concentration of chl a $\left(4.26 \mathrm{\mu g} \mathrm{l}^{-1}\right)$ yields a phytoplankton biomass of 0.16 and $0.44 \mathrm{mg} \mathrm{C}^{-1}$, accounting for 21.7 and $60.3 \%$, respectively, of the overall average POC concentration $\left(0.73 \mathrm{mg} \mathrm{C}^{-1}\right)$.

Similarly, a certain fraction of POC is composed of bacterioplankton biomass. This accounts for $19.7 \%$ of the overall average POC concentration. However, it should be noted that some fraction of bacterioplankton cells might be missed from the POC collection by GF/F filtration and thus from the POC determination. This may have caused overestimation of the bacterioplankton-C contribution to the total POC pool.

These estimates suggest that a certain fraction (only ambiguously estimated as 20 to $60 \%$ ) of total POC is composed of phytoplankton-C, and about $20 \%$ of POC was ascribable to bacterioplankton biomass. The remaining POC was assumed to be non-phytoplanktonic, non-bacterioplanktonic sources such as phytodetritus and terrigenous matter. The contributions of microzooplankton-C and net-zooplankton-C were negligible, accounting for only 0.1 to $3.9 \%$ and 1.8 to $4.8 \%$, respectively, of total POC in the Seto Inland Sea (Uye et al. 1996, Uye \& Shimazu 1997). The statistical observation that thraustochytrid abundance was most significantly correlated to POC concentration leads to the idea that thraustochytrid and POC are closely coupled, particularly the POC of non-phytoplankton and non-bacterioplankton-C. In contrast, bacterioplankton abundance was more highly correlated to chl a concentration and insignificantly correlated to POC concentration. This suggests that bacterioplankton abundance responds mainly to chl a concentration but not to the non-phytoplankton-dominated POC pool. The apparent coupling of thraustochytrid abundance and POC concentration implies certain functional activity of thraustochytrids, such as exoenzymatic degradation, on POM. Further study using concentrated DOM and POM on thraustochytrid growth is underway to evaluate the role of thraustochytrids in the production and cycling of aquatic organic materials.

Acknowledgements. The authors are grateful to the crew of the RV 'Toyoshio-maru', Hiroshima University, and the cruise participants for their on-board assistance. Prof. S. Uye, Hiroshima University, kindly offered opportunities for sample collection during the 'Toyoshio-maru' cruise. Part of this study was supported by the Hiroshima University Research Promotion Fund.

\section{LITERATURE CITED}

Banse K (1977) Determining the carbon-to-chlorophyll ratio of natural phytoplankton. Mar Biol 41:199-212

Biggs RB, Howell BA (1984) The estuary as a sediment trap: alternate approaches to estimating its filtering efficiency. In: Kennedy VS (ed) The estuary as a filter. Academic Press, London, p 107-129

Bird DF, Kalff J (1984) Empirical relationships between bacterial abundance and chlorophyll concentration in fresh and marine waters. Can J Fish Aquat Sci 41:1015-1023

Bird DF, Karl DM (1999) Uncoupling of bacteria and phytoplankton during the austral spring bloom in Gerlache Strait, Antarctic Peninsula. Aquat Microb Ecol 19:13-27

Bremer GB (1995) Lower marine fungi (Labyrinthulomycetes) and the decay of mangrove leaf litter. Hydrobiologia 295: 89-95

Bremer GB, Talbot G (1995) Cellulolytic enzyme activity in the marine protist Schizochytrium aggregatum. Bot Mar $38: 37-41$

Cavalier-Smith T, Allsopp MTEP, Chao EE (1994) Thraustochytrids are chromists, not fungi: 18S rRNA signature of Heterokonta. Phil Trans R Soc Lond B 346:387-397

Cho BC, Azam F (1990) Biogeochemical significance of bacterial biomass in the ocean's euphotic zone. Mar Ecol Prog Ser 63:253-259

Chrost RH, Faust MA (1983) Organic carbon release by phytoplankton: its composition and utilization by bacterioplankton. J Plankton Res 5:477-493

Cole JJ, Likens GE, Strayer DL (1982) Photosynthetically produced dissolved organic carbon: an important carbon source for planktonic bacteria. Limnol Oceanogr 27: 1080-1090

Cole JJ, Findlay S, Pace ML (1988) Bacterial production in fresh and saltwater ecosystem; a cross-system overview. Mar Ecol Prog Ser 43:1-10

Darley WM, Porter D, Fuller MS (1973) Cell wall composition and synthesis via golgi-directed scale formation in the marine eukaryote Schizochytrium aggregatum, with a note on Thraustochytrium sp. Arch Microbiol 90:89-106

Fell JW, Master IM (1973) Fungi associated with the decay of mangrove (Rhizophora mangle L.) leaves in South Florida. In: Stevenson LH, Colwell RR (eds) Estuarine microbial ecology. University of South Carolina Press, Columbia, p 455-466

Findlay RH, Fell JW, Coleman NK, Vestal JR (1986) Biochemical indicators of the role of fungi and thraustochytrids in mangrove detrital systems. In: Moss ST (ed) The biology of marine fungi. Cambridge University Press, Cambridge, p 91-104

Frank U, Rabinowitz C, Rinkevich B (1994) In vitro establishment of continuous cell cultures and cell lines from ten colonial cnidarians. Mar Biol 120:491-499

Fuhrman JA, Ammerman JW, Azam F (1980) Bacterioplankton in the coastal euphotic zone: distribution, activity, and possible relationships with phytoplankton. Mar Biol 60: 201-207

Gahan PB (1984) Plant histochemistry and cytochemistry. An introduction. Academic Press, New York

Heald EJ, Odum WE (1970) The contribution of marine swamps to Florida fisheries. Proc Gulf Caribb Fish Inst 22: 130-135

Hobbie JE, Daley RJ, Jasper S (1977) Use of Nuclepore filters for counting bacteria by fluorescence microscopy. Appl Environ Microbiol 33:1225-1228

Hullar MAJ, Fry B, Peterson BJ, Wright RT (1996) Microbial utilization of estuarine dissolved organic carbon: a stable 
isotope tracer approach tested by mass balance. Appl Environ Microbiol 62:2489-2493

Ittekkot V (1988) Global trends in the nature of organic matter in river suspensions. Nature 332:436-438

Kimura H, Naganuma T (2001) Thraustochytrids: a neglected agent of the marine microbial food chain. Aquat Ecosyst Health Manage 4:13-18

Kimura H, Fukuba T, Naganuma T (1999) Biomass of thraustochytrid protoctists in coastal water. Mar Ecol Prog Ser 189:27-33

Kuparinen J, Leonardsson K, Mattila J, Wikner J (1996) Food web structure and function in the Gulf of Bothnia, the Baltic Sea. Ambio Spec Rep 8:13-21

Larsson U, Hagström ^ (1979) Phytoplankton extracellular release as an energy source for bacterial growth in a pelagic ecosystem. Mar Biol 52:199-206

López-García P, Rodríguez-Valera F, Pedrós-Alió C, Moreira D (2001) Unexpected diversity of small eukaryotes in deep-sea Antarctic plankton. Nature 409:603-607

Miller JD, Jones EBG (1983) Observations on the association of thraustochytrid marine fungi with decaying seaweed. Bot Mar 26:345-351

Moon-van der Staay SY, Wachter RD, Vaulot D (2001) Oceanic 18S rDNA sequences from picoplankton reveal unsuspected eukaryotic diversity. Nature 409:607-610

Moran M, Hodson R (1994) Support of bacterioplankton production by dissolved humic substances from three marine environments. Mar Ecol Prog Ser 110:241-247

Moss ST (1986) Biology and phylogeny of the Labyrinthulales and Thraustochytriales. In: Moss ST (ed) The biology of marine fungi. Cambridge University Press, Cambridge, p 105-129

Naganuma T, Miura S (1997) Abundance, production and viability of bacterioplankton in the Seto Inland Sea, Japan. J Oceanogr 53:435-442

Naganuma T, Takasugi H, Kimura H (1998) Abundance of thraustochytrids in coastal plankton. Mar Ecol Prog Ser 162:105-110

Nakahara T, Yokochi T, Higashihara T, Tanaka S, Yaguchi T, Honda D (1996) Production of docosahexaenoic and docosapentaenoic acid by Schizochytrium sp. isolated from Yap Islands. J Am Oil Chem Soc 73:1421-1426

Okaichi T, Yanagi T (eds) (1997) Sustainable development in the Seto Inland Sea, Japan. Terra Scientific Publishing Co, Tokyo

Parsons TR, Maita Y, Lalli CM (1984) A manual of chemical and biological methods for seawater analysis. Pergamon Press, Oxford, p 173

Patterson DJ (1999) The diversity of eukaryotes. Am Nat 154(Suppl):96-124

Perkins FO (1973) Observations of Thraustochytriaceous (Phycomycetes) and Labyrinthulid (Rhizopodea) ectoplastomic nets on natural and artificial substrates - an electron microscope study. Can J Bot 51:485-492

Pearse AGE (1968) Histochemistry. Theoretical and applied, Vol 1. Churchill Livingstone, Edinburgh

Raghukumar S (1986) Morphology, taxonomy and ecology of thraustochytrids and labyrinthulids, the marine counterparts zoosporic fungi. In: Dayal MD (ed) Advances in zoosporic fungi. Publications PVT Ltd, New Delhi, p 35-60

Raghukumar S (1988) Schizochytrium mangrovei sp. nov., a

Editorial responsibility: Jed Fuhrman,

Los Angeles, California, USA thraustochytrid from mangroves in India. Trans Br Mycol Soc 90:627-631

Raghukumar S, Balasubramian R (1991) Occurrence of thraustochytrid fungi in corals and coral mucus. Indian $\mathrm{J}$ Mar Sci 20:176-181

Raghukumar C, Raghukumar S (1999) Thraustochytrid fungoid protests in faecal pellets of the tunicate Pegea confoederata, their tolerance to deep-sea conditions and implication in degradation processes. Mar Ecol Prog Ser 190:133-140

Raghukumar S, Schaumann K (1993) An epifluorescence microscopy method for direct detection and enumeration of the fungi-like marine protists, the thraustochytrids. Limnol Oceanogr 38:182-187

Raghukumar S, Rahukumar C, Rajendran A (1990) Abundance of thraustochytrid fungi in the Arabian Sea. Estuar Coast Shelf Sci 31:351-358

Raghukumar S, Sharma S, Raghukumar C, Sathe-Pathak V, Chandaramohan D (1994) Thraustochytrid and fungal component of marine detritus. IV. Laboratory studies on decomposition of leaves of the mangrove Rhizophora apiculata Blume. J Exp Mar Biol Ecol 183:113-131

Riemann F, Schaumann K (1993) Thraustochytrid protests in Antarctic fast ice. Antarct Sci 5:279-280

Rolff C, Elmgren R (2000) Use of riverine organic matter in plankton food webs of the Baltic Sea. Mar Ecol Prog Ser 197:81-101

Sathe-Pathak V, Raghukumar S, Raghukumar C, Sharma S (1993) Thraustochytrid and fungal component of marine detritus. I. Field studies on decomposition of the brown alga Sargassum cinereum J. Ag. Indian J Mar Sci 22: 159-167

Sharma S, Raghukumar Chandralata, Raghukumar S, SathePathak V, Chandaramohan D (1994) Thraustochytrid and fungal component of marine detritus. II. Laboratory studies on decomposition of the brown alga Sargassum cinereum J. Ag. J Exp Mar Biol Ecol 175:227-242

Ulken A (1984) The fungi of the mangal ecosystem. In: Pro FD, Dor I (eds) Hydrobiology of the Mangal. W Junk, The Hague, p 27-33

Uye S, Shimazu T (1997) Geographical and seasonal variations in abundance, biomass and estimated production rates of meso- and macrozooplankton in the Inland Sea of Japan. J Oceanogr 53:529-538

Uye S, Nagano N, Tamaki H (1996) Geographical and seasonal variations in abundance, biomass and estimated production rates of microzooplankton in the Inland Sea of Japan. J Oceanogr 52:689-703

Valiela I (1995) Marine ecological processes, 2nd edn. Springer-Verlag, New York

Yanagi T (1996) Currents and related problems in the Seto Inland sea. Phys Oceanogr Coast Processes VIII:110-120

Zimmermann R, Iturriaga R, Becker-Birck J (1978) Simultaneous determination of the total number of aquatic bacteria and the number of thereof involved in respiration. Appl Environ Microbiol 36:926-935

Zweifel UL, Norrman B, Hagström Å (1993) Consumption of dissolved organic carbon by marine bacteria and demand for inorganic nutrients. Mar Ecol Prog Ser 101:1-2

Zweifel UL, Wikner J, Hagström Å, Lundberg E, Norrman B (1995) Dynamics of dissolved organic carbon in coastal ecosystem. Limnol Oceanogr 40:299-305

Submitted: April 30, 2001; Accepted: August 8, 2001

Proofs received from author(s): September 20, 2001 